\title{
Elastic properties and structural observations of Distaloy SA powder sintered with boron and carbon
}

\author{
Własności sprężyste i obserwacje struktury \\ spiekanego proszku Distaloy SA z borem i węglem
}

\begin{abstract}
One of the methods aimed at increasing the density in PM parts is the process of activated sintering performed by adding boron as elementary boron powder, for example. Under this researchwork novel, PM materials were obtained based on prealloyed and diffusion bonded powder (type: Distaloy SA) with the following chemical composition: Fe-1.75\%Ni-1.5\%Cu-0.5\%Mo, with the addition of $0.55 \mathrm{wt} . \%$ carbon and boron $(0.2,0.4$ and $0.6 \mathrm{wt} . \%)$. Distaloy SA samples alloyed with carbon and boron were manufactured by mixing the powders in a Turbula mixer, then compacting the mixture in a hydraulic press under a pressure of $600 \mathrm{MPa}$ and sintered in a tube furnace at $1473 \mathrm{~K}$ for 60 minutes in a hydrogen atmosphere. The densification process of Distaloy SA parts with boron and carbon depends on the sintering mechanism. In order to evaluate the sintering mechanism of the PM samples, structural investigations using SEM/EDS were performed. During sintering of these materials at $1473 \mathrm{~K}$, a liquid phase is generated as a result of the reaction occurring between the alloy matrix and the complex of carbo-borides, which leads to a considerable degree of consolidation. The elastic properties of the sintered samples (such as Young's modulus and the damping coefficient) were measured in a tensile test with a Förster elastometer.
\end{abstract}

Keywords: Distaloy SA powder, boron, carbon, sintering, elastic properties

\section{Streszczenie}

Jedną z metod mających na celu zwiększenie gęstości części PM jest proces aktywnego spiekania, zachodzący np. w wyniku dodania boru w formie elementarnego proszku boru. W badaniach omawianych w niniejszym artykule nowoczesne materiały PM zostały uzyskane ze stopowanych i dyfuzyjnie związanych proszków Distaloy SA o składzie Fe-1,75\%Ni-1,5\%Cu-0,5\%Mo z dodatkiem 0,55\% wag. węgla i boru (0,2, 0,4 i 0,6\% wag.). Próbki Distaloy SA stopowane węglem i borem otrzymano w wyniku mieszania proszków w mieszalniku Turbula, a następnie zagęszczenia

Małgorzata Perek-Nowak Ph.D. Eng., Joanna Karwan-Baczewska D.Sc. Ph.D. Eng.: AGH University of Science and Technology, Faculty of Non-Ferrous Metals, Department of Materials Science and Non-Ferrous Metals Engineering, Krakow, Poland; jokaba@agh.edu.pl 
na prasie hydraulicznej pod ciśnieniem $600 \mathrm{MPa}$ i spiekania w piecu rurowym w temperaturze $1473 \mathrm{~K}$ w atmosferze wodoru przez $60 \mathrm{~min}$. Zagęszczanie części ze stopu Distaloy SA z borem i węglem zależy od mechanizmu spiekania. W celu określenia mechanizmu spiekania próbek PM dokonano obserwacji strukturalnych za pomocą SEM z przystawką EDS. Podczas spiekania omawianych materiałów w temperaturze $1473 \mathrm{~K}$ w wyniku reakcji pomiędzy osnową a złożonymi węglano-borkami tworzy się ciekła faza, która prowadzi do znacznej konsolidacji. Własności mechaniczne spiekanych próbek takie jak moduł Younga czy współczynnik tłumienia zostały zmierzone w próbie rozciągania i na elastometrze Förstera.

Słowa kluczowe: proszek Distaloy SA, bor, węgiel, spiekanie, własności sprężyste

\section{Introduction}

Activated sintering can be regarded as one of the simplest methods aimed at increasing the density of produced steel parts. The first researchers who studied activated sintering initiated by the addition of boron in iron alloys were Madan and German [1]. They proved that boron enhances the sintering with the presence of a liquid phase and activates the diffusion/sintering process in the solid state.

The mechanical properties of steels sintered with boron were analyzed in [2-5], while the explanation of the sintering mechanism for these alloys can be found in [6-9]. It was observed that, during the sintering of Fe-Mo-B-C materials, an eutectic reaction between the alloy matrix and complex carbo-borides decreases the sintering temperature and leads to the formation of a liquid phase, thus improving consolidation and the mechanical properties. Additionally, with an increased Mo content (3-5\%), the amount of the liquid phase decreases at the grain boundaries, while larger quantities of molybdenum borides and carbo-borides evolve inside the grains [10].

\section{Experimental methods}

A prealloyed and diffusion-bonded Distaloy SA powder was used with the following composition: Fe1.75\%Ni-1.5\%Cu-0.5\%Mo. The powder supplied by the Höganäs company was mixed with the addition of carbon and boron in a Turbula mixer for 15 minutes. Carbon in the form of graphite was added to the powder in the amount of $0.55 \mathrm{wt}$.\%; for comparison, samples without carbon were also prepared. Boron was introduced into the mixture in three concentrations: $0.2,0.4$, and 0.6 wt.\%. Next, the powder mixtures were subjected to compression in a hydraulic press under a pressure of $600 \mathrm{MPa}$, followed by sintering in a hydrogen atmosphere at $1473 \mathrm{~K}$ for 60 minutes. The relative density of the mentioned powders was about $90 \%$; the highest relative density (94 wt.\%) was noted for the sample of Distaloy SA with 0.6 wt.\% B.

The Young modulus was measured in a tensile test $(\mathrm{E})$ and with a Förster elastometer $\left(\mathrm{E}_{\mathrm{OF}}\right)$. The data is collected in Tables 1 and 2. 
Table 1. Properties of sintered Distaloy SA powder with boron (without C)

\begin{tabular}{|c|c|c|c|}
\hline B content [wt.\%] & $\mathbf{E}[\mathrm{MPa}]$ & $\mathbf{E}_{\mathbf{0 F}}[\mathrm{MPa}]$ & $\mathbf{R}_{\mathbf{0 . 0 2}}[\mathrm{MPa}]$ \\
\hline 0 & 83,303 & 149,991 & 159 \\
\hline 0.2 & 105,385 & 157,984 & 197 \\
\hline 0.4 & 118,967 & 173,336 & 312 \\
\hline 0.6 & 118,000 & 185,831 & 361 \\
\hline
\end{tabular}

Table 2. Properties of sintered Distaloy SA powder with 0.55 wt.\% C and boron

\begin{tabular}{|c|c|c|c|}
\hline B content [wt.\%] & $\mathbf{E}[\mathrm{MPa}]$ & $\mathbf{E}_{\mathbf{0 F}}[\mathrm{MPa}]$ & $\mathbf{R}_{\mathbf{0 . 0 2}}[\mathrm{MPa}]$ \\
\hline 0 & 151,615 & 194,249 & 143 \\
\hline 0.2 & 96,492 & 161,442 & 253 \\
\hline 0.4 & 101,253 & 173,741 & 436 \\
\hline 0.6 & 81,129 & 183,151 & 95 \\
\hline
\end{tabular}

The ultrasonic Young's modulus $\mathrm{E}_{\mathrm{OF}}$ was determined based on a frequency of resonant vibrations:

where:

$$
E_{0 F}=4 C l^{2} \times f^{2} \times \rho \times 10^{-7}[\mathrm{MPa}]
$$

C - constant dependent on the sample's shape,

$I$ - total length of the sample $[\mathrm{cm}]$,

$f$ - resonant vibration frequency $[1 / \mathrm{s}]$,

$\rho-$ density of the analyzed material $\left[\mathrm{g} / \mathrm{cm}^{3}\right]$.

Additionally, at the mentioned elastometer, damping coefficients $v_{f \Delta}$ and $v_{f k}$ were determined; $v_{f \Delta}$ was determined from the width of the resonant peak at the level of the half resonant amplitude:

$$
v_{f \Delta}=\frac{\pi\left(f_{2}-f_{1}\right)}{\sqrt{33 f}}
$$

where:

$f_{1}$ - frequency smaller than the resonant one, at the half-resonant frequency,

$f_{2}$ - frequency higher than resonant one, at the half-resonant frequency.

Besides, an average logarithmic vibration decrement was established based on the following equation:

$$
v_{n}=\frac{1}{n}
$$

where $\mathrm{n}$ is the number of cycles of free-damping vibrations with a diminishing amplitude from the resonant one $A_{0}$ to $A_{0 / e^{*}}$ 
Additionally, X-ray diffraction spectra were collected for the remnants of the dissolved Distaloy SA with boron as well as with boron and carbon sinters.

Structural observations were conducted with a Hitachi S-3400N scanning electron microscope (SEM) with a Thermo Noran energy dispersive spectrometer (EDS) attachment at an accelerating voltage of $20 \mathrm{kV}$.

\section{Results and discussion}

The plastic properties of these sinters are described in detail in research-work [5]. Here, the elastic properties will be discussed. It is observed that Young's modulus value differs upon the measuring method: the $E$ value is lower than $E_{0 F}$ by 31 to $49 \%$ in the case of the carbon-free samples and by 22 to $56 \%$ in the case of the carbon-enriched samples. Young's modulus $\mathrm{E}$ increases strongly with the addition of $0.55 \mathrm{wt} . \% \mathrm{C}$ in the boron-free specimens, from $83 \mathrm{GPa}$ up to $151 \mathrm{GPa}$ (see Tables 1 and 2 and Figure 1). On the contrary, carbon showed a slightly reducing effect on the value of Young's modulus $E$ in the samples with the addition of boron.

In the case of proof stress $R_{0.02}$, the samples with no carbon nor boron content showed higher yield points (see Tables 1 and 2). The samples with 0.2 and 0.4 wt.\% B have a higher $\mathrm{R}_{0.02}$ value if $0.55 \mathrm{wt} . \% \mathrm{C}$ is introduced to the mixture. The highest value for $\mathrm{R}_{0.02}(436 \mathrm{MPa}$ ) is observed in the sintered Distaloy SA-0.55 wt.\% C- 0.4 wt.\% B sample, while the smallest (only $95 \mathrm{MPa}$ ) is reported for Distaloy SA-0.55 wt.\% C-0.6 wt.\% B.

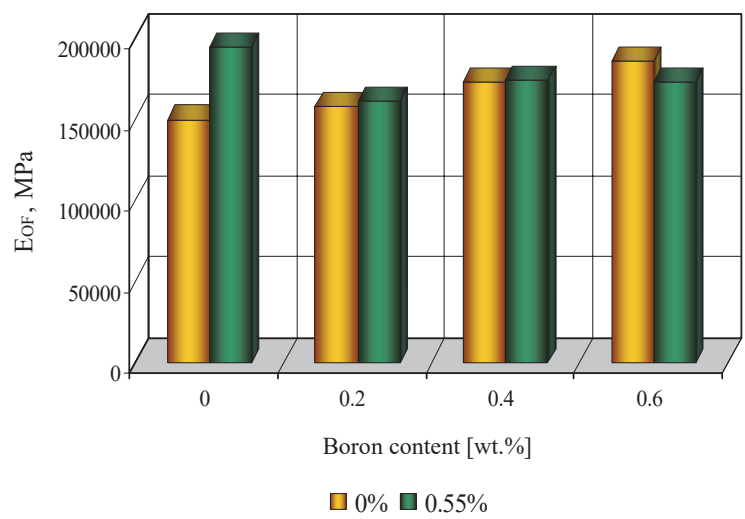

Fig. 1. Effect of boron on Young's modulus $E_{\text {oF }}$ of Distaloy SA sinters with carbon and boron additions

The change of damping coefficient $v_{f \Delta}$ is presented in Figure 2. The value of $v_{f \Delta}$ is the highest in the sample with $0.55 \mathrm{wt} . \% \mathrm{C}$ and decreases then with increasing amounts of boron. In the samples to which graphite was not added, $v_{f \Delta}$ is almost the same for the 
samples with boron content 0 to $0.4 \mathrm{wt} . \% \mathrm{~B}$ and then decreases for the sample with 0.6 wt.\% B.

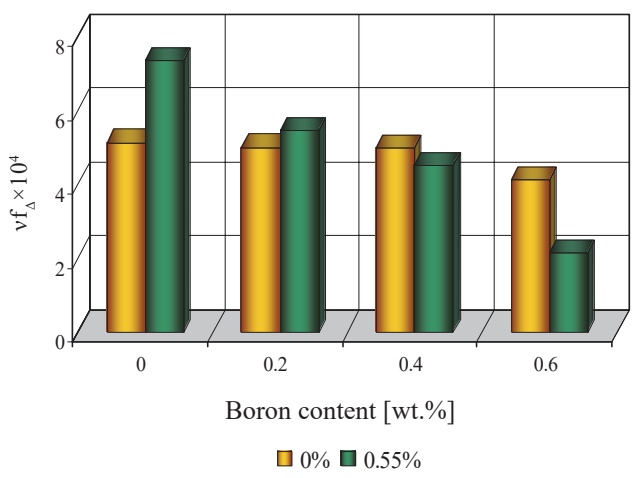

Fig. 2. Effect of boron on damping coefficient $v_{f \Delta}$ of Distaloy SA sinters with carbon and boron additions

Average logarithmic vibration decrement $v_{n}$ is presented in Figure 3 . It is the highest in the sample with $0.55 \% \mathrm{C}$ and without boron. Then, it rapidly decreases to a value of $12 \times 104$ and is kept at this level for the analyzed samples with various boron contents of 0.2 and 0.4 wt.\% B; then, it decreases strongly to about $4.6 \times 104$ for the sample with $0.6 \mathrm{wt} . \% \mathrm{~B}$. In the case of samples without the addition of carbon, the vn value increases moderately (up to about $13.7 \times 104$ for $0.6 \mathrm{wt} . \%$ B).

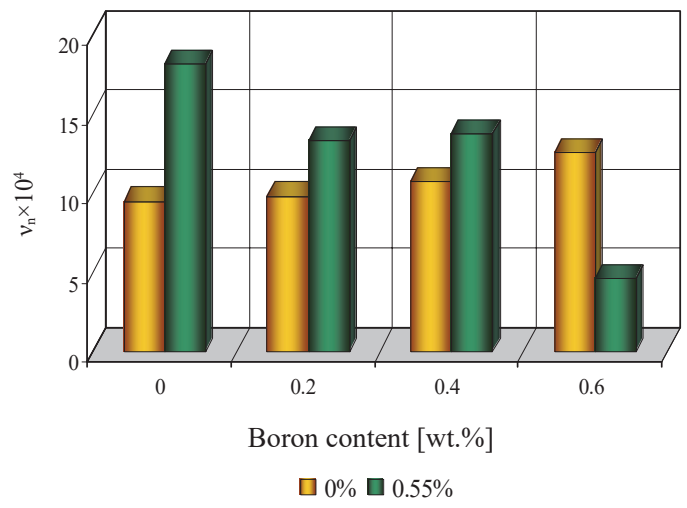

Fig. 3. Effect of boron on average logarithmic vibration decrement $v_{n}$ of Distaloy SA sinters with carbon and boron additions

Additionally, the sample with the highest content of boron and another one with boron and carbon were analyzed by means of the X-ray diffraction technique to 
determine compounds formed during the sintering process. The respected spectra are presented in Figures 4 and 5 . It was found that, in the activated sintering process, the following compounds are formed in the Distaloy $S A$ with 0.6 wt.\% B specimen: $\mathrm{Fe}_{2} \mathrm{~B}$, $\mathrm{FeMo}_{2} \mathrm{~B}_{2}$, and $\mathrm{NiB}$; while, in the sample made of Distaloy $\mathrm{SA}$ with $\mathrm{C}$ and $\mathrm{B}-\mathrm{Fe}_{2} \mathrm{~B}, \mathrm{NiB}$, and $\mathrm{Mo}_{2} B$ are present. As mentioned in $[6,11-15]$, the effective role of the borides is to decrease the sintering temperature and increase the amount of liquid phase. It is also to note that, in the samples containing carbon, cementite $\mathrm{Fe}_{3} \mathrm{C}$ is formed.

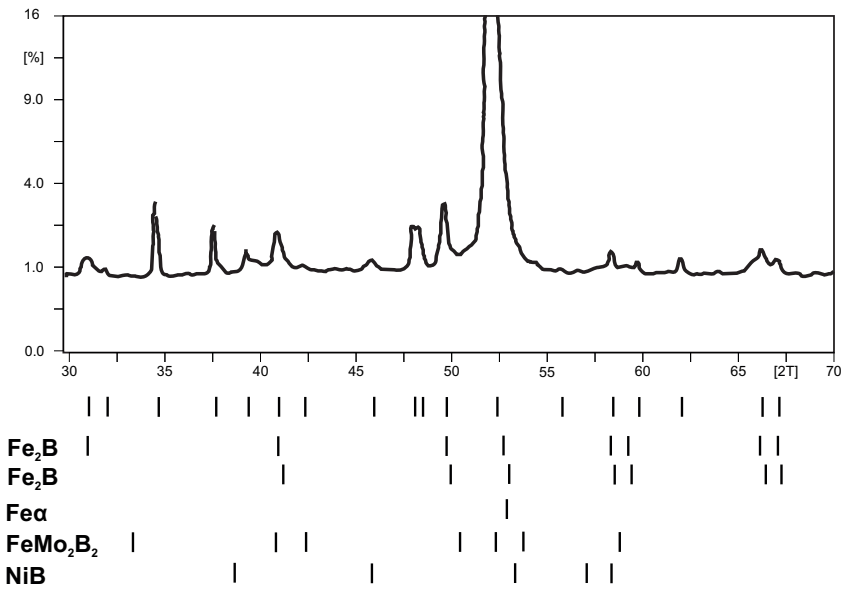

Fig. 4. XRD spectrum for Distaloy SA with 0.6 wt.\% B sinter. Position of reference peaks for given phases marked as lines below the spectrum

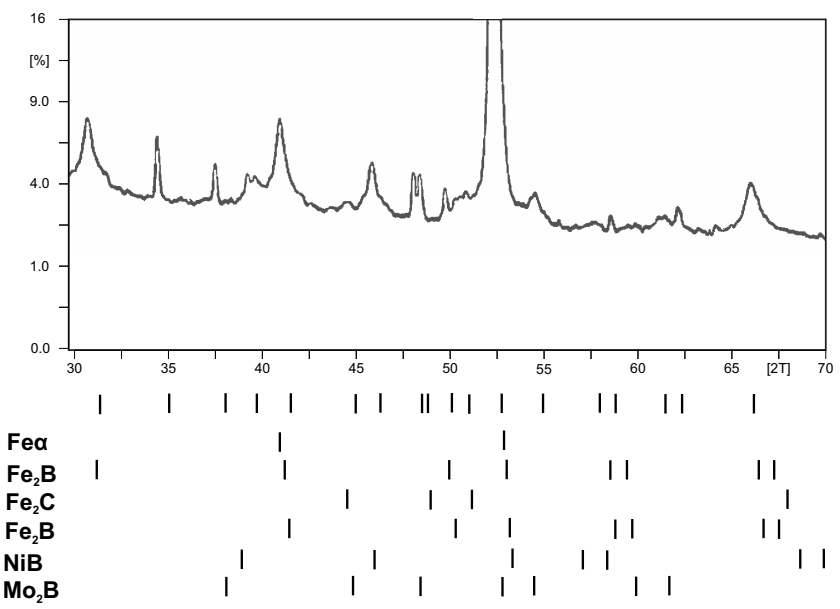

Fig. 5. XRD spectrum for Distaloy SA with $B$ and $C$ sinters. Position of reference peaks for given phases marked as lines below the spectrum 
The elastic properties of Distaloy SA sinters with the addition of boron or with the addition of both boron and carbon are strongly connected with the sintering process of the powder's mixture; i.e., with the formation of a liquid phase. The liquid phase forms due to a eutectic reaction between the alloyed matrix, iron borides, and borides of the alloying elements ( $\mathrm{FeMo}_{2} \mathrm{~B}_{2}, \mathrm{NiB}$, and $\mathrm{Mo}_{2} \mathrm{~B}$ ) at a temperature of $1473 \mathrm{~K} \mathrm{(Figs.} 4$ and 5). The resulting liquid phase leads to a significant densification of the Distaloy $S A$ sinters and a considerable increase in elastic modulus $\left(\mathrm{E}_{\mathrm{OF}}\right)$ up to a boron concentration of $0.4 \mathrm{wt} . \% \mathrm{~B}$.

At a higher boron content ( $0.6 \mathrm{wt} . \%)$, a too-big amount of the liquid phase is generated at the grain boundaries, which inhibits the further increase of the elastic properties. The mentioned process is confirmed in structural observation (SEM, XRD, Fig. 6).

a)

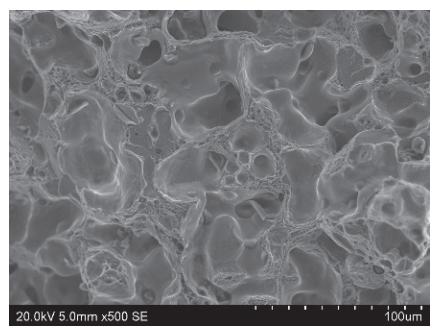

b)

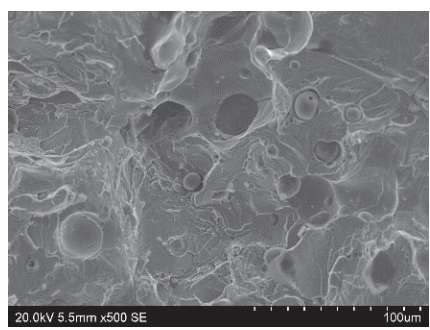

c)

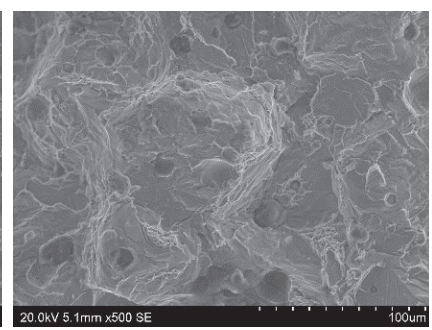

Fig. 6. Fracture surface of Distaloy SA sintered powder with: a) $0.2 \mathrm{wt} . \% \mathrm{~B}$ and $0.55 \mathrm{wt} . \% \mathrm{C}$; b) $0.4 w t . \%$ B and 0.55 wt.\% C; and c) $0.6 w t . \% B$ and 0.55 wt.\% C; magnification of $500 \times$

During the sintering of the Distaloy SA powder with boron or boron and carbon, a reaction of boron with the alloying elements occurs at first, and a boride phase or carbide phase is generated due to the diffusion of iron, molybdenum, and nickel to boron as well as the diffusion of iron to boron and carbon. Iron, molybdenum, and nickel consist of a part of the boride phase that forms eutectics as well as precipitates formed both at the grain boundaries and within the ferrite grains. The liquid phase dissolves iron particles subsequently precipitating at the grain boundaries, giving a hardening effect. In the case of sinters with the addition of boron and carbon, carbon was also identified in the eutectic.

\section{Summary}

The elastic properties of the studied materials depend on the density and porosity. Sinters with lower density are characterized by a lower initial Young's modulus $E_{O F}$ and higher values of damping coefficients $v_{f \Delta}$ and $v_{f k}$. 
In Distaloy SA sinters with an increase in boron content, the initial Young modulus $\mathrm{E}_{\mathrm{oF}}$ increases, while the damping coefficients show a decreasing trend. The presented characteristics prove that the damping coefficients depend on such factors as boron content, density, and porosity, where the dominating factors are the densities of the samples. The higher the boron concentration in a specimen, the higher the density and lower the porosity.

At a temperature of $1473 \mathrm{~K}$, the liquid phase forms as a result of the eutectic reaction between the alloyed matrix, iron borides, and borides of the alloying elements, which leads to the densification of Distaloy sinters as well as a considerable increase in elastic modulus $\left(\mathrm{E}_{\mathrm{OF}}\right)$ up to a boron concentration of $0.4 \mathrm{wt} . \%$. The X-ray diffractogram showed the presence of $\mathrm{FeMo}_{2} \mathrm{~B}_{2}, \mathrm{NiB}$, and $\mathrm{Mo}_{2} \mathrm{~B}$ compounds in the analyzed sinters.

\section{Acknowledgement}

Financial support of the State Committee for Scientific Research of Poland under grant number 11.11.180.653 is acknowledged.

\section{References}

[1] Madan D.S., German R.M.: Enhanced sintering of iron alloyed with B, C, P, Mo, Ni. Proceedings of the 1986 International Powder Metallurgy Conference and Exhibition "The Future of Powder Metallurgy, P/M '86', Düsseldorf, 7-11 July 1986, 1223-1226

[2] Toennes C., Ernst P., Meyer G., German R.M.: Full density sintering by boron addition in a martensitic stainless steel. Advanced in Powder Metallurgy \& Particulate Materials, 3 (1992), 371-381

[3] Karwan-Baczewska J.: The properties and structure of boron modified P/M iron-molybdenum alloys. Archives of Metallurgy, 46 (2001), 439-445

[4] Karwan-Baczewska J.: Spiekane stopy na bazie proszku żelaza modyfikowane borem. Rozprawy. Monografie. AGH Uczelniane Wydawnictwa Naukowo-Dydaktyczne, Kraków 2008

[5] Karwan-Baczewska J.: Processing of Distaloy SA sintered alloys with boron and carbon. Archives of Metallurgy and Materials, 60 (2015), 41-45

[6] Bucse I., Ionescu A., Nicolicescu C., Ghercioin J.: Studies regarding the influence of boron addition on the hardness and friction coefficient of the $\mathrm{Mn}, \mathrm{Mo}$ and $\mathrm{Cr}$ ecological alloyed sintered steels. International Conference on Economic Engineering and Manufacturing System, Brasov, 24-25 November 2011, 1-4

[7] Karwan-Baczewska J., Rosso M.: Properties of P/M molybdenum alloyed steels modified with boron. Proceedings of the 8th International Scientific Conference AMME, Gliwice-Rydzyna-Pawłowice-Rokosowo, 24-27 October 1999, 665-668

[8] Karwan-Baczewska J.: Właściwości nowych spiekanych stali molibdenowych modyfikowanych borem. Rudy i Metale Nieżelazne, 48, 6 (2003), 279-284

[9] Perek-Nowak M., Karwan-Baczewska J.: Influence of molybdenum and boron addition on fracture of P/M parts. Key Engineering Materials, 682 (2016), 265-269

[10] Sarasola M., Tojal C., Castro F.: Study of boron behavior during sintering of Fe/Mo/B/C alloys to near full density. Euro PM2004 Conference Proceedings, Vienne, Austria, 17-21 October 2004, 3, 319-326

[11] Sarasola M., Gomez-Acebo T., Castro F.: Liquid generation during sintering of Fe-3.5\%Mo powder compacts with elemental boron. Acta Materialia, 52 (2004), 4615-4622 
[12] Bolina R., German R.M.: Supersolidus sintering of boron doped stainless steel powder compacts. Conference Proceedings: Euro PM 2004, Powder Metallurgy World Congress \& Exhibition, Vienna, Austria, 17-21 October 2004. Powder manufacturing and processing, miniaturisation and nanotechnology in PM, ed. Herbert Danninger; Raimund Ratzi

[13] Sarasola M., Gomez-Acebo T., Castro F.: Microstructural development during liquid phase sintering of Fe and Fe-Mo alloys containing elemental boron additions. Powder Metallurgy, 48 (2005), 59-67

[14] Karwan-Baczewska J.: The properties of Fe-Ni-Mo-Cu-B materials produced via liquid phase sintering. Archives of Metallurgy and Materials, 56 (2011), 789-796

[15] Kuroki H.: A review on the effect and behavior of boron in sintered iron and steel. Journal of the Japanese Society of Powder Metallurgy, 48 (2001), 293-304 